\title{
Model of Financing Infrastructure Development in Bandung, West Java, Indonesia
}

\author{
Poni Sukaesih Kurniati \\ Department of Government Science, \\ Universitas Komputer Indonesia \\ Bandung, Indonesia \\ poni.sukaesih@email.unikom.ac.id
}

\author{
Suryanto \\ Department of Business Administration, \\ Universitas Padjadjaran \\ Bandung, Indonesia
}

\author{
Sri Dewi Anggadini \\ Department of Accounting, \\ Universitas Komputer Indonesia \\ Bandung, Indonesia
}

\begin{abstract}
This study aims to find a model for financing infrastructure development. This research method is explorative qualitative and carried out in Bandung City, West Java Province, Indonesia. Data collection techniques include literature studies and in-depth interviews. The results showed that the budget allocation for infrastructure development in the Regional Expenditure Budget (APBD) was still very lacking. This happens because the budget allocation is still more for personnel expenditure. Therefore, the Bandung City Government is looking for funding sources other than the APBD to build the infrastructure. There are three financing models carried out by the Bandung City Government to finance infrastructure development, namely: (1) conventional models, (2) transitional models, and; (3) ideal model (budget sustainability). Financing with conventional models fully relies on the budget allocation of funds from the APBD. Transitional financing combines the budget from the APBD and partnerships with other parties. Whereas the fully financing ideal financing model is financed by the non-regional budget. To realize the ideal model it is necessary to work together with various parties synergistically by considering three aspects, namely: partners to partner, forms of cooperation, and implementation period.
\end{abstract}

Keywords - financing models, development, infrastructure, APBD

\section{I.INTRODUCTION}

Infrastructure financing is the capital expenditure made by the government in order to provide access and facilities. So far infrastructure financing has only relied on funding sources from the Regional Budget (APBD). The limited sources of APBD financing have resulted in constrained infrastructure development. Opportunities to find financing sources become open in line with regional autonomy.

The implementation of regional autonomy demands the creativity of regional leaders to explore the potential of their regions. Regional autonomy also gives full authority in managing finances in their respective regions. In fact, local governments generally have not been able to perform their functions and roles efficiently, especially in regional financial management [1].

Every local government is expected to be able to promote socio-economic development for the local population [2]. The development of an area should indeed come from within the region. The development comes through the will and desire of the people in the area [3].

Regional autonomy policy is considered a policy that benefits regions that have potential resources. However, for regions that lack potential resources, the regional autonomy policy is an unfavorable policy [4]. This opinion is consistent with previous research which states that local governments have unequal abilities in each region [5].

The local government in collaboration with the Regional Representative Council determines the general policy direction and budget priorities first as a guide [6]. Law Number 32 of 2004 concerning the regional government which is a package of legislation with Law No. 33 of 2004 concerning the financial balance between the central and regional governments, opens up the widest possible opportunity for local governments to explore all their best potential. That way, each region will have one or more specific advantages relative to other regions [7].

Regional finance in Indonesia has almost the same characteristics, namely the very low portion of own regional revenues or Regional Original Revenues (PAD) that can be used for public and regional interests [5]. This can be seen from the low proportion of PAD to total regional income when compared to the number of transfers from the central government [8]. In Law Number 33 of 2004, regional financial resources come from PAD, balancing funds, regional loans, and other legitimate revenues. PAD, consists of regional taxes, regional retributions, the profit share of regionally owned enterprises, and other regional revenues [9].

Regional development is a manifestation of the main task for a regional government. Regional development functions can take the form of physical development, as well as human resource development. To carry out the development function, the local government needs funding sources that are usually obtained through APBD. The amount of funding needed to support regional development programs certainly cannot be entirely financed by the available APBD, there are still many development programs that have not been touched by APBD financing.

Infrastructure development that is believed to be able to increase the rate of economic growth, has so far not received a reasonable proportion due to budget constraints. 
Likewise, in the Bandung City APBD, it indicates that there is a high gap between personnel expenditure and capital expenditure including infrastructure. Local governments are required to optimize their potential income by providing a greater proportion of capital expenditure for infrastructure development [10].

To avoid the widening gap between the need and the availability of adequate infrastructure, anticipatory steps need to be taken. Local governments should look for alternative financing solutions to fund programs that have not been touched by the APBD. The alternative financing for the shortage of the APBD is derived from funds that actually do not burden the local government in the future. By looking at the budget conditions as mentioned above, the local government is required to find and explore alternative funding schemes beyond what has been traditionally and conventionally implemented under the APBD scheme.

There are several studies related to infrastructure financing. Infrastructure can be financed by cooperation between the government and the private sector with a Public Private Partnership (PPP) scheme and Corporate Social Responsibility (CSR) needs to continue to get support from all parties concerned [11], [12]. While other researchers say there are three different schemes to finance additional infrastructure in the urban growth model. This analysis compares the cost schemes for two types of cost sharing schemes, which reduce the impact on urban growth and the value of land from the transfer to the cost-impact scheme. An efficient financing scheme was also identified [13], [14].

\section{METHOD}

This study uses a qualitative approach with a type of explorative descriptive research. The explorative descriptive research aims to describe the state of a phenomenon. This research is not intended to test certain hypotheses but only describes what is a variable, symptom or condition. The phenomenon in this research is the characteristic of financing infrastructure development used by the Bandung City Government.

The data source used consists of primary and secondary data. Primary data is obtained through interviews and observations, while secondary data is obtained through searches of literature studies and documentation studies. This research was conducted in Bandung City, West Java Province, Indonesia.

Data analysis techniques are carried out by triangulating sources and types of data. Interpretation is done referring to the theory, the results of previous studies, the opinions of experts, and the sharpness of the researchers' thinking.

\section{RESULTS AND DISCUSSION}

Since the enactment of Law No. 32 of 2004 concerning regional autonomy, there have been many changes in the governance system and policies both national and regional. One of them relates to regional financial management. The policy basics regarding fundamental changes in finance include those set forth in Law Number 17 of 2003 concerning State Finance, Law Number 15 of 2004 concerning Inspection of the Management and Responsibility of State Finance, Government Regulation Number 24 of 2005 which contains standards in preparation of Financial Statements for the Central Government and Regional Governments, Law Number 33 of 2004 concerning Financial Balance between the Central Government and Regional Governments.

The existence of these changes is expected the local government, including the City of Bandung Government can increase independence in financial management and regional development. Thus, the Bandung City government is required to be ready to face challenges in managing its own regional finances.

APBD financing is actually capable if the Bandung City Government has fiscal independence. For that, the Bandung City Government is required to innovate and improve in all units of the work unit in order to create a creative economy [15]

The birth of Law Number 22 of 1999 which was subsequently renewed Law No. 32 of 2004 and Law No. 25 of 1999 which was amended Law No. 33 of 2004 concerning the regional financial balance between central and regional governments marks the start of regional autonomy in Indonesia. Regional autonomy provides clear and tangible authority and is accountable to each region proportionally which is realized by the principles of democracy, community participation, equality, and justice as well as potential and diversity.

The main characteristics of an area capable of carrying out autonomy are (1) the ability of regional finances, which means that the area has the ability and authority to explore financial resources, manage and use its own finances to finance government administration; (2) Dependence on central assistance must be as minimal as possible, therefore, PAD must be the largest financial source supported by central and regional financial balance policies [16].

Actually, the City Government of Bandung has both of these characteristics. Both of these characteristics will affect the pattern of relations between the central and regional governments. Conceptually, the pattern of financial relations between the central and regional governments must be in accordance with the ability of the regions to finance the implementation of government. Therefore, to see the ability of the regions in carrying out regional autonomy, one of them can be measured through regional financial performance [17]. 
Measuring regional financial performance can be used the degree of fiscal decentralization between central and regional governments. The measurement of its performance by comparing PAD with total regional revenues. The pattern of relations with regional capabilities in terms of finances in Table 1.1.

TABLE 1. RELATIONSHIP PATTERNS AND LEVELS OF REGIONAL CAPABILITIES

\begin{tabular}{|c|c|c|}
\hline $\begin{array}{c}\text { Financial } \\
\text { Capability }\end{array}$ & Independence (\%) & Relationship Pattern \\
\hline Very low & $0 \%-25 \%$ & Instructive \\
\hline low & $25 \%-50 \%$ & Consultative \\
\hline Medium & $50 \%-75 \%$ & Participatory \\
\hline High & $75 \%-100 \%$ & Delegative \\
\hline
\end{tabular}

Based on Table 1 above, the higher the degree of independence of a region indicates that the area is increasingly able to finance its own expenditure without assistance from the central government. When combined with the degree of fiscal decentralization used to see the contribution of PAD to regional revenues as a whole, the regional financial performance will be seen as a whole.

In general, the higher the contribution of the PAD and the higher the ability of the region to finance its own capacity will show a positive regional financial performance. In this case, positive financial performance can be interpreted as regional financial independence in financing regional needs and supporting the implementation of regional autonomy in the region. Thus, the smaller the funding needed that comes from the nonregional budget.

By looking at the budget challenges as mentioned above, the Bandung City Government is required to seek and explore alternative funding schemes beyond what has been traditionally and conventionally implemented. Several schemes that have been implemented to finance infrastructure development in the city of Bandung found three financing models, namely: (1) conventional models; (2) transitional models; and (3) ideal models.

\section{A. Conventional Model}

The conventional model is a financing model that relies heavily on or relies heavily on local government budgets. There are no or not many partnerships in order to obtain non-government funding sources. This model is found in the majority of infrastructure that is the object of research such as the construction of roads, bridges, and local government buildings.

\section{B. Transitional Model}

Transitional models are models that still rely on government budgets, but not fully, which is $70 \%$ of the total budget needed. While the shortcomings must be sought by the management or infrastructure manager, among others through improving service functions; partnership programs with the business community and society; and competitive programs.

The government budget is specifically intended for operational or routine activities, while development is pursued through partnerships. This model has been implemented in arranging Taman Tegal Lega and building bus shelters.

\section{Ideal Model}

The ideal model is financing based on sustainable financing patterns. In this model, the infrastructure is selffinanced by a business entity that cooperates with the local government, both in the form of initial investment and maintenance. The sources of costs are obtained from the partnership, whether the partnership with the business world or the community. Thus the institution does not depend on the government budget. The ideal financing model prioritizes financial independence in financing infrastructure development, especially in the construction and maintenance of infrastructure.

One ideal model as explained by Syahrir, et al (2017) is the scheme of regional government cooperation with a business entity (PPP) or generally more commonly known as a Public-Private Partnerships (PPP) scheme. [18]. PPP is a scheme of infrastructure provision and financing based on cooperation between the government and business entities (private). The infrastructure service delivery scheme for the public interest is based on an agreement (contract) between the government represented by the Regional Government, which is referred to as the Person in charge of the Cooperation Project (PJPK) and the private sector, taking into account the principle of risk sharing among the parties.

PPP schemes can potentially support the improvement of the quality of APBD in terms of reducing APBD pressure to allocate capital expenditure for infrastructure at the beginning of the project. However, actually, the PPP scheme also has many other advantages which in some cases can also improve the quality of the APBD directly or indirectly.

PPP membership, among others, can create better budgeting, because it can reduce unexpected costs including some cost overrun and time overrun. Better budgeting can also be created from a strong linkage between budget and performance. This is because the PPP scheme for payments for infrastructure services can be linked to the quality of service availability. Other members of the PPP scheme can also improve the quality of public services. The involvement of the private sector in project design and the dynamics created in PPP schemes in the bidding process can encourage innovation and better efficiency. Then, another advantage of PPP is that there is higher accountability. PPP projects in their implementation involve more stakeholders who monitor the project in more detail, not only project owners but also 
business entities and lenders. This model was found in the financing made in the manufacture of several parks.

In the provision of infrastructure through PPP, cooperation between the PJPK and the business entity can be carried out in several model structures. This depends on the scope of services to cooperate with the private sector whether it includes designing, building, financing, operating, maintenance or other coverage. The difference in modalities depends on the characteristics of infrastructure services that will be cooperated and planned from the relevant sector GCA. The different types of PPP schemes can also occur due to differences in funding sources or return on investment from projects that are cooperated.

PPP projects can be based on payments from users based on levies on user charges or availability by local governments based on availability payment. User charge or user fee payment schemes are schemes in PPP projects where the project receives funding and returns on investments derived from levies on user usage of services provided by the business entity.

Infrastructure projects that use user charge schemes are projects that can more easily and clearly generate income. Whereas the availability payment scheme is a scheme in PPP projects where the return on investment of business entities comes from payments made by the government.

\section{CONCLUSION}

From the description above it can be concluded that the financing of infrastructure development in the region can be done from several sources. The sources of financing, among others, come from the original sources of regional revenues contained in the APBD and from non-APBD financing or a combination of APBD and nonAPBD. Infrastructure financing can be grouped into three financing models, namely; (1) conventional models, (2) transitional models, and; (3) ideal model (budget sustainability). To realize the ideal model it is necessary to work together with various parties synergistically by considering three aspects, namely: partners to partner, forms of cooperation, and implementation period. Seeing the condition of infrastructure in the city of Bandung that is not optimal, local governments need to increase the ideal financing model. However, the central government also needs to conduct special interventions, for example through Special Allocation Funds, Deconcentration Funds, or other funding assistance.

\section{REFERENCES}

[1]. Badu, Edward, et al. "Analysis of strategic issues underpinning the innovative financing of infrastructure within developing countries." Journal of Construction Engineering and Management 139.6 (2012): 726-737.

[2]. Burra, Sundar. "Towards a pro-poor framework for slum upgrading in Mumbai, India." Environment and Urbanization17.1 (2005): 67-88.

[3]. Budiharjo, Eko. Sejumlah Masalah Permukiman Perkotaan.Bandung: Alumni. (1997).
[4]. Abiko, Alex, et al. "Basic costs of slum upgrading in Brazil." Global Urban Development Magazine 3.1 (2007).

[5]. Gupta, Devendra B. Urban housing in India. Vol. 1. World Bank, (1985)..

[6]. Myers, Dowell, John Pitkin, and Julie Park. "Estimation of housing needs amid population growth and change." Housing Policy Debate 13.3 (2002): 567-596.

[7]. Suryanto, and Budiman Rusli. "Analysis of economy aspects in the policy on establishing housing and settlement in West Java, Indonesia." International Journal of Trade and Global Markets 10.1 (2017): 91-98.

[8]. Field, Erica. "Property rights and investment in urban slums." Journal of the European Economic Association 3.2-3 (2005): 279-290.

[9]. Hasrul Rizka1, Agus Purwoko, dan Rujiman. Perencanaan Penanganan Kawasan Pemukiman Kumuh di Kelurahan Tanjung Tiram Kabupaten Batubara, Serambi Engineering, Volume III, Edisi Khusus, Februari (2018)..

[10]. Shankar, Sharada, and Ann Klassen. "Influences on fruit and vegetable procurement and consumption among urban AfricanAmerican public housing residents, and potential strategies for intervention." Family Economics and Nutrition Review 13.2 (2001): 34

[11]. Basri, Faisal H. Tantangan dan Peluang Otonomi Daerah, Jurnal Pada Lintasan Ekonomi, Volume XVII, Nomor I, Juli-Desember 2000, Lembaga Penerbitan dan Puublikasi Ilmiah Fakultas Ekonomi Universitas Brawijaya, Malang (200)..

[12]. Elmi, Bachrul. Analisa Obligasi Untuk Membiayai Pembangunan Daerah (Municipal Bonda) Kasus Pemda Propinsi Jawa Barat. Working Paper (2005)..

[13]. Okta, Dewi dan David Kaluge, Analisis Peuang obligasi daeran sebagai sumber alternatif pembiayaan Derah, Journal Indonesia Apply of Economics, 5. 2, (2011): 157-171.

[14]. Marmot, Michael, et al. "Closing the gap in a generation: health equity through action on the social determinants of health." The lancet 372.9650 (2008): 1661-1669.

[15]. Nice, David C. "The impact of state policies to limit debt financing." Publius: The Journal of Federalism 21.1 (1991): 6982.

[16]. Isunju, John Bosco, et al. "Financing of sanitation services in the slums of Kampala and Dar es Salaam." Health 5.4 (2013): 783791. 